\title{
KEANEKARAGAMAN JENIS IKAN DI KAWASAN MANGROVE SUNGAI KAKAP KABUPATEN KUBU RAYA PROVINSI KALIMANTAN BARAT
}

\author{
(Species Diversity fish in mangrove foresh sungai kakap district Kubu Raya regengy \\ Kalimantan Barat Province)
}

\author{
Stefanus Anton Asan, M. Sofwan Anwari, Slamet Rifanjani, Herlina Darwati \\ Fakultas Kehutanan Universitas Tanjungpura Pontianak. J1. Daya Nasional Pontianak 78124 \\ Email: antonasan702@gmail.com
}

\begin{abstract}
Forest mangrove constitute some ecosystem estuaria with system that apoplectic terbuka open and amenable nutrition pretty material organic and non organic along sediment from circle terrestrial. Literally ecology forest mangrove have a role urgent inside guard awkwaedness live water the sea and coastal. Literally economical, some research show that mangrove gives contributions to fish resources revolved 30\%-44,18\% the mangrove region a habitat for the various of fish, even some types of fish do breeding in the mangrove area. This research is aimed at exploring the diversity in the river mangrove area kakap district Kubu Raya Province Borneo. Methods that used inside research here that is perposive sampling using tools catch nets and dragnet with 10 supprssant on broads 50 meter and installation draget at any dot observations. Samples taken in the show 6 points of observation within 100 meters. The setting of the sample points was done in the labyrinth $p$ the mangrove orest, which is fine, moderate and badly demaged. Observations in the mangrove conditions affect the diversity of fish such as fine, moderate, and degraded conditions, the result is evidenced by accounts based on the reddish diersity in each observation station on this study is found as many as 5 different fish.
\end{abstract}

Keyword: Fish, Mangrove, Species Diversity Of Fish

\section{PENDAHULUAN}

Indonesia memiliki ekosistem mangrove terluas di dunia. Menurut Dirjen RLPS Departemen Kehutanan untuk tahun 1999 potensi mangrove di Indonesia dengan mendasarkan pada sebaran sistem lahan yang di tumbuhi mangrove adalah seluas 9,2 juta hektar, luasan tersebut terdiri atas kawasan hutan negara 3,7 juta hektar dan non hutan 5,5 juta hektar (Poedjirahajoe et al. 2013). Sedangkan menurut Giri et al 2011 sumber lainnya, mangrove terluas ditemukan di Asia terutama di Indonesia yaitu 3,1 juta hektar atau sekitar $22,6 \%$ dari luas mangrove di dunia.

Struktur mangrove yang komplek menyebabkan ekosistem mangrove memiliki produktifitas tinggi yang kaya akan bahan organik sehingga berperan penting sebagai daerah perkembangbiakan dan asuhan bagi ikan komersial (Nagi 2008). Mangrove memiliki peran dan fungsi sebagai daerah perputaran unsur hara atau nutrien dan juga sebagai penopang kehidupan berbagai biota akuatik yang hidup dan berasosiasi di dalamnya Pramudji (2008). Mangrove berfungsi diantaranya sebagai tempat pemijahan beberapa jenis biota akuatik, tempat bersarangnya jenis burung migran dan juga habitat primata dan reptil (Irwanto 2006).

Ikan merupakan salah satu biota laut yang hidup dan berkembangbiak di kawasan mangrove. Ikan merupakan 
hewan bertulang belakang (vertebrata) yang hidup dalam air dan memiliki insang yang berfungsi untuk mengambil oksigen yang terlarut dari air dan sirip digunakan untuk berenang. Kawasan mangrove sungai kakap merupakan tempat berkembangbiak biota-biota laut salah satunya ikan. Sejalan dengan peningkatan jumlah penduduk, serta perkembangan teknologi maka permintaan akan sumber daya alam juga meningkat demikian pula akan permintaan terhadap sumber daya ikan. Pemanfaatan sumber daya alam di hutan mangrove dapat mengakibatkan rusaknya habitat tempat tinggal ikan sehingga menggangu populasi ikan tersebut.

Kondisi hutan mangrove Sungai Kakap saat ini mengalami penurunan kualitas, hal ini disebabkan adanya aktifitas sehari-hari warga masyarakat sekitar kawasan hutan mangrove Sungai Kakap yang sering memanfaatkan hutan mangrove sebagai bahan kebutuhan sehari-hari seperti budidaya tambak dan kebutuhan rumah tangga (kayu bakar). Pemanfaatan kayu yang berlebihan pada kawasan hutan mangrove menyebabkan dampak negatif bagi keanekaragaman biota-biota perairan seperti ikan.

\section{METODE PENELITIAN}

Penelitian dilaksanakan 17 Mei 2018 sampai 14 juni 2018 di kawasan mangrove Sungai Kakap, Kecamatan Sungai Kakap, Kabupaten Kubu Raya, Kalimantan Barat dengan lama waktu \pm 4 minggu efektif di lapangan. Objek penelitian yaitu keberagaman jenis ikan di kawasan mangrove Sungai Kakap, Kecamatan Sungai Kakap, Kabupaten Kubu Raya.
Alat yang digunakan dalam penelitian antara lain : jala, pukat, ember, formalin, kamera, GPS, kertas packing, peta lokasi penelitian, kamera, tally sheet dan buku identifikasi.

Penentuan titik sampling

Penentuan titik sampling dilakukan dengan purposive sampling disesuaikan dengan kondisi mangrove berdasarkan kondisi lingkungan bagus sedang dan rusak. Penelitian dilaksanakan pada kawasan mangrove sungai kakap Kabupaten Kubu Raya. Pengambilan sampel diulang sebanyak tiga kali.

Pengambilan Sampel Ikan

Pengambilan sampel ikan dilakukan dengan menggunakan alat tangkap jala dan pukat dengan 10 kali penebaran pada luasan 50 meter dan pemasangan pukat disetiap titik pengamatan. Pengambilan sampel pada penelitian ini terdapat 6 stasiun pengamatan dengan jarak 100 meter. Penentuan titik pengambilan sampel dilakukan pada kondisi hutan mangrove, yaitu bagus, sedang dan rusak berat.

\section{Pengukuran Faktor Lingkungan Perairan}

Pengukuran faktor lingkungan perairan dilakukan bersamaan dengan pengambilan sampel ikan. Faktor lingkungan perairan yang diukur di lapangan yaitu kedalaman air, $\mathrm{pH}$ air, salinitas dan vegetasi disekitar kawasan mangrove sungai kakap.

\section{Analisis Data}

Analisis data digunakan rumus menurut Ferinita (2007).

Indeks Dominansi (indeks of Dominance) /

(C)

$\mathrm{C}=\sum(n i / N)^{2}$ 
Dimana :

ni $=$ jumlah individu suatu jenis

$\mathrm{N}=$ jumlah individu seluruh jenis

Nilai indeks berkisar antara 0-1

$\mathrm{C}=0$, berarti tidak terdapat jenis yang mendominasi jenis lainnya

C $=1$, berarti terdapat jenis yang mendominasi jenis lainnya

Indeks Keanekaragaman Jenis (Indeks of Diversity) Shannon- Weaver / (H), Ferinita (2007)

$H^{\prime}=-\sum_{i=1}^{n}\left({ }_{\mathrm{i}} / N\right) \operatorname{In}\left(n_{i} / N\right)$

Dimana :

$\mathrm{H}^{\prime}=$ indeks keanekaragaman

$\mathrm{S}=$ jumlah jenis ikan

$\mathrm{N}=$ jumlah individu ikan

$\mathrm{ni}=$ jumlah individu ikan tiap jenis ke-i

Kriteria :

$\mathrm{H}^{\prime}<1=$ keanekaragaman jenis rendah

$1<\mathrm{H}^{\prime}<3=$ keanekaragaman jenis sedang

$\mathrm{H}^{\prime}>3=$ keanekaragaman jenis tinggi

Indeks Kekayaan Jenis (Species Richness) Margalef $/(R)$

$R=\frac{S-1}{\operatorname{In}(N)}$

Dimana : $\mathrm{N}=$ Jumlah seluruh individu.

$\mathrm{S}=$ Jumlah jenis

Kriteria : $\mathrm{R}<3,5$ : Rendah

: R 3,5-5 : Sedang

: R > 5 : Tinggi

Indeks Kemerataan Jenis (Species

Evennes) Pielou /(E)

$$
E=\frac{H^{\prime}}{\operatorname{In}(S)}
$$

Dimana :

H' = indeks kemerataan Shannon-Weaver

$\mathrm{S}=$ jumlah jenis

Nilai indeks berkisar 0-1

$\mathrm{E}=0$, berarti kemerataan jenis rendah
$\mathrm{E}=1$, berarti kemerataan antar jenis relatif merata/sama

Indek Kesamaan Jenis Menurut Sorensen

(IS) dengan rumus :

$$
I S=\frac{2 C}{A+B} \times 100 \%
$$

Keterangan :

$\mathrm{S}=$ indeks kesamaan Sorensen

$A=$ jumlah spesies dalam sampel lokasi $A$

$\mathrm{B}=$ jumlah spesies dalam sampel lokasi $\mathrm{B}$

$\mathrm{C}=$ jumlah spesies yang terdapat di lokasi

A dan B

Kriteria indeks kesamaan jenis sebagai

berikut :

$1-30 \%=$ Kategori rendah

$31-60 \%=$ Kategori sedang

$61-91 \%=$ Kategori tinggi

HASIL DAN PEMBAHASAN

\section{Kondisi Perairan Sungai Kakap}

Secara umum warna air sungai kakap berwarna kuning bening pada pagi hari dan pada sore hari ketika air pasang maka air sungai kakap menjadi keruh, dan pada saat itulah ikan-ikan kecil kembali mendekat di pinggiran hutan mangrove. Dasar perairan di sekitar mangrove sungai kakap penuh dengan lumpur serta pada tepian hutan mangrove d itumbuhi banyak tumbuhan sejenis palem seperti nipah (Nypa fruticans), Pidadah Merah (Sonneratia caseolaris), Pulut-pulut (Kandelia candel). Nipah adalah tanaman yang mendominasi di lokasi penelitian mangrove sungai kakap. Nipah adalah sejenis palem yang tumbuh dilingkungan hutan mangrove atau daerah pasang surut dekat tepi laut. 


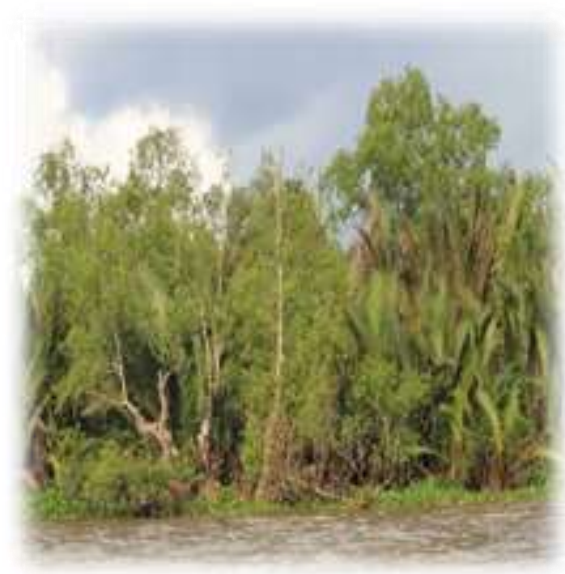

Picture 1. Conditions behind the mangrove river Kakap, 2018

Komposisi Jenis Ikan Sungai Kakap Masing-masing stasiun penelitian

Berdasarkan hasil penelitian didapatkan sebanyak 5 jenis ikan yaitu
Tetradon nigroviridis, Ambassis nalua, Scatophagus argus, Rasbora tornieri, Hexanematichthys sagor.

Tabel 1 Daftar Jenis dan Jumlah ikan di lokasi penelitian.

\begin{tabular}{cclcccccc}
\hline \multirow{2}{*}{ No } & \multirow{2}{*}{ Family } & \multirow{2}{*}{ Nama Jenis } & \multicolumn{1}{c}{ Jumlah } \\
\cline { 3 - 8 } & & & $\mathbf{1}$ & $\mathbf{2}$ & $\mathbf{3}$ & $\mathbf{4}$ & $\mathbf{5}$ & $\mathbf{6}$ \\
\hline 1 & Tetraodontidae & Tetradon nigroviridis & 7 & 11 & 13 & 8 & 5 & 5 \\
2 & Ambassidae & Ambassis nalua & 12 & 10 & 15 & 18 & 11 & 18 \\
3 & Scatophagidae & Scatophagus argus & 3 & 1 & 6 & 9 & 7 & 4 \\
4 & Cyprinidae & Rasbora tornieri & - & - & 8 & 9 & 8 & 3 \\
5 & Ariidae & Hexanematichthys sagor & - & - & 4 & 7 & 5 & 2 \\
\hline
\end{tabular}

Sumber: Analisis Data, 2018

Komposisi jenis ikan sungai kakap yang terdapat di lokasi penelitian dapat diketahui dari perhitungan indeks indeks kemerataan jenis dan indeks kekayaan jenis yang dapat dilihat pada dominan, indeks keanekaragaman jenis, tabel 2 berikut ini :

Tabel 2. Indeks Dominansi, Keanekaragaman, Kemerataan , dan Kekayaan Jenis ikan di lokasi penelitian.

\begin{tabular}{lcccccc}
\hline \multirow{2}{*}{\multicolumn{1}{c}{ Indeks }} & \multicolumn{7}{c}{ Stasiun } \\
\cline { 2 - 7 } & $\mathbf{1}$ & $\mathbf{2}$ & $\mathbf{3}$ & $\mathbf{4}$ & $\mathbf{5}$ & $\mathbf{6}$ \\
\hline Dominansi (C) & 0,42 & 0,46 & 0,24 & 0,23 & 0,22 & 0,37 \\
Keanekaragaman Jenis (H') & 0,91 & 0,84 & 1,50 & 2,35 & 1,56 & 1,27 \\
Kemerataan Jenis (E) & 0,83 & 0,77 & 0,93 & 1,46 & 0,97 & 0,79 \\
Kekayaan Jenis (R) & 0,65 & 0,65 & 1,04 & 1,02 & 1,17 & 1,15 \\
\hline
\end{tabular}

Sumber : Analisis Data, 2018

Keterangan :

Stasiun1 dan 2 kondisi mangrove rusak.

Stasiun 2 dan 3 kondisi mangrove bagus.

Stasiun 4 dan 6 kondisi mangrove sedang. 


\section{Indeks Dominansi}

Indeks dominansi jenis diperoleh berdasarkan dari jumlah individu yang dijumpai pada lokasi pengamatan, semakin besar jumlah individu yang ditemukan maka semakin besar nilai indeks dominansinya. Nilai indeks dominansi ini menggambarkan pengelompokan individu yang lebih terpusat pada suatu lokasi pengambilan data dan bukan menggambarkan penyebaran jenis tersebut.

Penelitian pada stasiun 1 sampai 6 menunjukkan bahwa tidak adanya jenis yang mendominasi suatu spesies lainya pada kawasan mangrove sungai kakap dari data menunjukkan indeks dominansi jika $\mathrm{C}=0$ berarti tidak adanya species yang mendominasi jenis lainnya, jika $\mathrm{C}=1$ maka ada jenis yang mendominasi jenis lainnya. Hal ini disebabkan kondisi stasiun 1 dan 2 kondisi mangrovenya rusak dan dekat dengan permukiman. Hasil pengamatan lansung berdasarkan metode perhitungan indeks dominansi menunjukkan indeks dominansinya rendah hal ini disebabkan mangrove sungai kakap sudah terganggu warga masyarakat sungai kakap.

\section{Keanekaragaman Jenis}

Berdasarkan hasil penelitian terlihat adanya perbedaan jenis yang teramati pada lokasi penelitian, hal tersebut menunjukkan tingkat keanekaragaman jenis ikan yang terdapat di kawasan mangrove sungai kakap cukup beragam. Keanekaragaman tersebut dikarenakan lokasi pengamatan memiliki perbedaan lingkungan antara lingkungan bagus, sedang dan rusak, Keberagaman yang cukup banyak dapat dijumpai di stasiun 3,4,5 dan 6 sedangkan stasiun 1 dan 2 kurang beragam dikarenakan kondisi lingkungan yang rusak dan dekat dengan permukiman warga setempat.

Kondisi lingkungan mangrove
sangat berpengaruh terhadap
keanekaragaman jenis ikan yang ada di kawasan sungai mangrove sungai kakap, terdapat beberapa jenis ikan yang teramati di stasiun 3 dan 4 yang kondisi lingkungannya bagus sebanyak 5 jenis atau sebanyak 97 individu, dan dengan nilai indeks keanekaragaman 1,50 dan 2,35. Berdasarkan nilai indeks keanekaragaman jenis kriteria $<1$ : keanekaragaman jenis rendah, $1<\mathrm{H} 3<$ : keanekaragaman jenis sedang dan $>3$ keanekaragaman jenis tinggi, dari hasil pengamatan stasiun 3 dan 4 tergolong keanekaragaman jenisnya sedang, sedangkan stasiun 1 dan 2 dengan nilai indeks keanekaragaman stasiun $1: 0,91$ dan jalur $2: 0,84$ termasuk kriteria keanekaragaman jenis rendah dan stasiun 5 dan 6 dengan nilai indeks keanekaragaman stasiun $5: 1,56$ dan stasiun $6: 1,27$ termasuk kriteria keanekaragaman sedang. Penyebabnya kondisi mangrove 1 dan 2 dekat dengan permukiman warga sungai kakap sedangkan 3,4,5 dan 6 jauh dari permukiman warga sungai kakap.

\section{Kemerataan Jenis}

Hasil dari analisis data mengenai kemerataan jenis ikan di kawasan mangrove sungai kakap menunjukkan bahwa banyak atau kurangnya jenis ikan yang masih ada di kawasan 
mangrove sungai kakap tergantung dengan kondisi lingkungan yang ada di kawasan mangrove sungai kakap. Penelitian dikawasan mangrove sungai kakap dibagi tiga kondisi lingkungan yang diamati yakni kondisi rusak, sedang dan bagus, untuk ketiga kriteria kondisi lingkungan tersebut ditetapkanlah secara sengaja untuk mengetahui kemerataan jenis ikan dikawasan mangrove sungai kakap, dengan kondisi rusak pada stasiun 1 dan 2 untuk kondisi bagus pada stasiun 3 dan 4 dan untuk kondisi lingkungan sedang pada stasiun pengamatan 5 dan 6 didapatkan hasil perhitungan dari ketiga kondisi lingkungan.

$$
\text { Hasil perhitungan indeks }
$$
kemerataan jenis tersebut jika dikaitkan dengan kriteria indeks kemerataan jenis yaitu $\mathrm{E}=0$ kemerataan rendah dan $\mathrm{E}=$ 1 kemerataan antar jenis relatif merata/sama, maka indeks kemerataan jenis pada lokasi penelitian mangrove sungai kakap manunjukkan kemerataan jenisnya tergolong rendah. Kondisi ini disebababkan aktifitas warga sehari-hari yang memamfaatkan hutan mangrove sungai kakap.

\section{Indeks Kekayaan Jenis}

Indeks kekayaan jenis merupakan nilai atau rasio perbandingan jenis antara jumlah jenis secara keseluruhan terhadap jumlah individu jenis yang terdapat pada lokasi penelitian. Berdasarkan analisis data mengenai kekayaan jenis ikan yang terdapat pada kawasan mangrove sungai kakap dapat diketahui jumlah total individunya dari stasiun 1 sampai stasiun 6 dengan ketiga kondisi lingkungan yang berbeda yakni rusak,sedang dan bagus.

Total individu ikan yang ditemukan adalah 209 ekor, dilokasi rusak stasiun 1 dan 2 terdapat 3 jenis ikan sebanyak (44 individu), stasiun 5 dan 6 sebanyak 5 jenis dan (68 individu), stasiun 3 dan 4 terdapat 5 jenis (97 individu). Berdasarkan kriteria nilai indeks kekayaan jenis nilai $\mathrm{R}<3,5$ termasuk rendah, $\mathrm{R}<3,5<5$ termasuk sedang dan $\mathrm{R}>5$ tinggi. Berdasarkan perhitungan indeks kekayaan jenis pada lokasi penelitian mangrove sungai kakap stasiun 1 dan 2 termasuk kriteria rendah, stasiun 3 dan 4 termasuk kriteria sedang dan stasiun 5 dan 6 termasuk kriteria sedang. Penyebab rendahnya indeks kekayaan jenis pada stasiun 1 dan 2 dikarenakan stasiun 1 dan 2 sangat dekat dengan permukiman warga sedangkan stasiun $3,4,5$ dan 6 jauh dari permukiman warga sungai kakap serta aktifitas sehari-hari masyarakat sungai kakap yang berdampingan dengan lokasi penelitian.

\section{Indeks Kesamaan Jenis}

Penelitian di kawasan mangrove sungai kakap tentunya tidak terlepas dari kesamaan jenis ikan yang ada di lingkungan rusak maupun bagus tentunya terdapat jenis yang sama, dengan indeks kesamaan jenis dapat diketahui persentase kesamaan jenis ikan yang ada di kawasan mangrove sungai kakap pada stasiun 1 sampai dengan stasiun 6. Berdasarkan hasil penelitian di lokasi kawasan mangrove sungai kakap terdapat kesamaan jenis, seperti jenis Tetradon nigroviridis dapat 
ditemui di stasiun 1 dan juga ditemukan di stasiun 2,3,4,5, dan 6 oleh sebab itu perlunya perhitungan indeks kesamaan jenis.

Hubungan kesamaan jenis ikan pada lokasi penelitian mangrove sungai kakap antara lingkungan rusak, sedang dan bagus kriteria indeks kesamaan jenisnya yaitu 1 sampai $30 \%$ termasuk kategori rendah, 31 sampai 60 termasuk kategori sedang dan 61 sampai 91 termasuk kategori tinggi. Hasil dari perhitungan indeks kesamaan jenis lokasi penelitian mangrove sungai kakap dari stasiun 1 sampai dengan stasiun 6 termasuk kriteria jenis kesamaannya tergolong tinggi. Hal ini dibuktikan dengan hasil pengamatan lansung dilapangan jenis-jenis ikan di stasiun 1,2,3,4,5 dan 6 relatif sama. Kesamaan jenis relatif sama disebabkan lokasi penelitian antar stasiun mempunyai kondisi yang sama hanya berbeda lingkungan dan jenis-jenis ikan yang ditangkap di lokasi penelitian sungai kakap relatif sama.

Tabel 3. Indeks Kesamaan Jenis (IS) Ikan di Sungai Kakap

\begin{tabular}{cc}
\hline Stasiun Pengambilan Sampel & IS \\
\hline Bagus dan sedang & $60 \%$ \\
Bagus dan rusak & $75 \%$ \\
Sedang dan rusak & $75 \%$ \\
\hline
\end{tabular}

Sumber Analisis Data, 2018

KESIMPULAN DAN SARAN

Hasil

dari

penelitian

keanekaragaman jenis ikan di habitat mangrove sungai kakap didapatkan 209 individu jenis ikan yang tergolong kedalam 5 famili, dengan tiga kriteria tingkat gangguan lingkungan berbeda yakni lingkungan bagus, sedang dan rusak. Keanekaragaman jenis ikan di stasiun 1 dan 2 tergolong rendah disebabkan dekat dengan permukiman serta aktifitas sehari-hari yang cukup tinggi di stasiun tersebut menyebabkan keanekaragaman rendah, stasiun 3,4,5,6 keanekaragaman sedang karena jauh dari permukiman serta jauh dari aktifitas sehari-hari masyarakat di kawasan mangrove Sungai Kakap Kabupaten Kubu Raya.

Mengingat peranan kawasan mangrove Sungai Kakap sebagai kawasan penyangga keberlangsungan hidup jenis biota air seperti ikan, maka perlu diperhatikan dan dilakukan manajemen kawasan mangrove Sungai Kakap yang lebih baik. Menginggat akan pentingnya data dan informasi berbagai potensi sumber daya alam mangrove Sungai Kakap khususnya keanekaragaman jenis ikan, diperlukan suatu penelitian lanjutan yang berkesinambungan.

\section{DAFTAR PUSTAKA}

Adrim 2010. Panduan Penelitian Untuk Ikan Laut, Pusat Penelitian Oseanografi-LIPI, Jakarta.

Giri C O E., Tieszen, L L., Zhu, Z., Singh, A., Loveland, T., Duke, N. 2011. Status and distribution of mangrove forests of the world using earth observation satellite data. Global Ecology and Biogeography, 20(1), 154-159. 
Irwanto . 2006. Keanekaragaman Fauna Pada Habitat Mangrove. www.irwantoshut.com. 24 mei 2018

Nagi H M 2008. Enviromental Studies on Mangrove Cover Changes in Goa, and Its Resident Crassostrea Population Thesis. National Institute of Oceanography. Dona Paula. India.www.drs.nio.org,pdf.

Poedjirahajoe E N P D. Mahayani, B R Shidarta dan M. Salamuddin.
2013. Tutupan Lamun dan Kondisi Ekosistemnya di Kawasan Pesisir Madasanger, Jelenga, dan Maluk Kabupaten Sumbawa Barat. Ilmu dan Teknologi Kelautan Tropis. 5(1):36-46.

Pramudji. 2008. 10 Tahun Lagi Mangrove Diperkirakan Habis. Surat Kabar Kompas Sabtu 14 Juni 2008. 